\title{
KAJI EKSPERIMENTAL HIDROFOBISITAS DAUN DENGAN VARIASI VOLUME DAN BAHAN DROPLET
}

\author{
Rachmat Subagyo ${ }^{1)}$, Dedy muliadi $^{2}$ \\ ${ }^{1,2}$ Program Studi Teknik Mesin Fakultas Teknik Universitas Lambung Mangkurat \\ JL. Akhmad Yani Km.36 Banjarbaru, Kalimantan Selatan, 70714 \\ Telp. 0511-4772646, Fax 0511-4772646 \\ E-mail : dedymuliadins@gmail.com
}

\begin{abstract}
Based on the measurement of droplet contact angle on the surface of taro leaf, droplet measurement using mineral water volume $1-5 \mathrm{ml}$ respectively that is $159,325^{\circ}, 154,628^{\circ}$, $152,430^{\circ}, 151,833^{\circ}, 150,199^{\circ}$, while in sea water that is $154,011^{\circ}, 152,266^{\circ}, 149,265^{\circ}$, $149,290^{\circ}, 144,345^{\circ}$, and on cooking oil that is $35,407^{\circ}, 40,206^{\circ}, 42,825^{\circ}, 46,997^{\circ}$, $49,807^{\circ}$. Based on the measurement of droplet contact angle on the surface of serai leaf, droplet measurement using mineral water volume $1-5 \mathrm{ml}$ respectively that is $132,791^{\circ}$, $130,539^{\circ}, 126,367^{\circ}, 124,409^{\circ}, 122,005^{\circ}$, while at sea water that is $126,319^{\circ}, 121,409^{\circ}$, $118,856^{\circ}, 109,273^{\circ}, 106,950^{\circ}$ and on cooking oil that is $34,683^{\circ}, 36,760^{\circ}, 39,739^{\circ}$, $43,603^{\circ}, 52,837^{\circ}$. Based on the measurement of droplet contact angle on papaya leaf surface, droplet measurements using mineral water are $87,766^{\circ}, 83,538^{\circ}, 82,248^{\circ}$, $74,157^{\circ}, 71,079^{\circ}$, while in sea water $84,523^{\circ}, 83,059^{\circ}, 80,017^{\circ}, 71,346^{\circ}, 70,167^{\circ}$, and on cooking oil are $34,367^{\circ}, 38,086^{\circ}, 40,597^{\circ}, 43,933^{\circ}, 47,339^{\circ}$. With the difference in fluid in each leaf, it can be seen the nature of the leaf, different leaves and different fluids in droplet droplets become related to the surface causing a decrease in contact angle.
\end{abstract}

Keywords : droplet contact angle, surface, nature of the leaf, decrease

\section{PENDAHULUAN}

Semakin pesatnya perkembangan teknologi nano saat ini menjadi suatu topik yang popular dalam kehidupan. Banyak teknologi dikembangkan dengan mengunakan material nano yang dibuat oleh para ahli dengan tujuan untuk memperoleh hasil yang lebih maksimal. Saat ini para ilmuan mengembangkan teknologi meniru cara kerja alam yang dikenal dengan istilah biomimetics. Salah satu fenomena fisika yang menarik di alam adalah sifat hidropobik dari daun.

Hidrofobik berasal dari kata Hidro (air) dan phobos (takut) adalah sifat takut air atau anti air. Sifat hidrofobik bisa dijumpai di alam contohnya permukaan daun yang selalu bersih dan tak terlihat basah meski terkena air. Jika ada kotoran menempel pada permukaan maka kotoran tersebut akan terhalau oleh air yang menggelinding dipermukaan tersebut. Kondisi hidrofobik suatu permukaan dapat diketahui dengan mengukur sudut kontak yang terbentuk pada permukaan. Sudut kontak didefinisikan sebagai sudut yang terbentuk antara droplet dengan permukaan padat yang kontak ketika droplet diteteskan. 


\section{Tinjauan Pustaka}

Permukaan yang memiliki sudut kontak antara $90^{\circ}-150^{\circ}$ disebut hidrofobik. Untuk permukaan yang memiliki sudut kontak $>150^{\circ}$ disebut dengan istilah superhydrophobic, permukan yang memiliki sudut kontak antara $10^{\circ}-90^{\circ}$ disebut dengan istilah hydrophilic sedangkan untuk yang memiliki sudut kontak $<10^{\circ}$ disebut dengan istilah superhydrophilic.(Karthick B dan Ramesh Maheshwari. 2008).

Penelitian yang akan dilakukan yaitu penelitian sifat superhidrofobik sebagai pengembangan dari bidang NanoTechnology yang sangat bermanfaat dalam bidang teknik mesin. Manfaat dari sifat superhidrofobik sangat banyak antara lain dalam bidang teknik mesin dan kehidupan sehari-hari. Kerugian gesekan yang sangat kecil merupakan hal yang sangat diperlukan dalam permesinan, sehingga mengurangi energi yang diperlukan dalam suatu proses konversi energi. Gesekan yang sangat kecil ini mampu diperoleh dari bahan-bahan superhidrofobik. Untuk mengkaji lebih dalam mengenai sifat superhidrofobik ini maka akan di teliti "Kaji Eksperimental Hidrofobisitas Daun dengan Variasi Volume dan Bahan Droplet”. Ada pun bahan droplet yang digunakan adalah air murni, air asin dan minyak goreng.

\section{2a. Dasar - dasar Superhidrofobisitas}

Secara umum, sifat permukaan membran dibagi menjadi dua, yaitu hidrofilik dan hidrofobik. Pada membran hidrofilik, air akan membasahi membran secara spontan. Sedangkan pada membrane hidrofobik, pembasahan membran oleh air tidak terjadi. Hidrofobisitas suatu membran dapat diindikasikan dengan nilai kontak, histeris sudut kontak dan sudut geser. Ditunjukkan pada Gambar 1, dibawah ini:

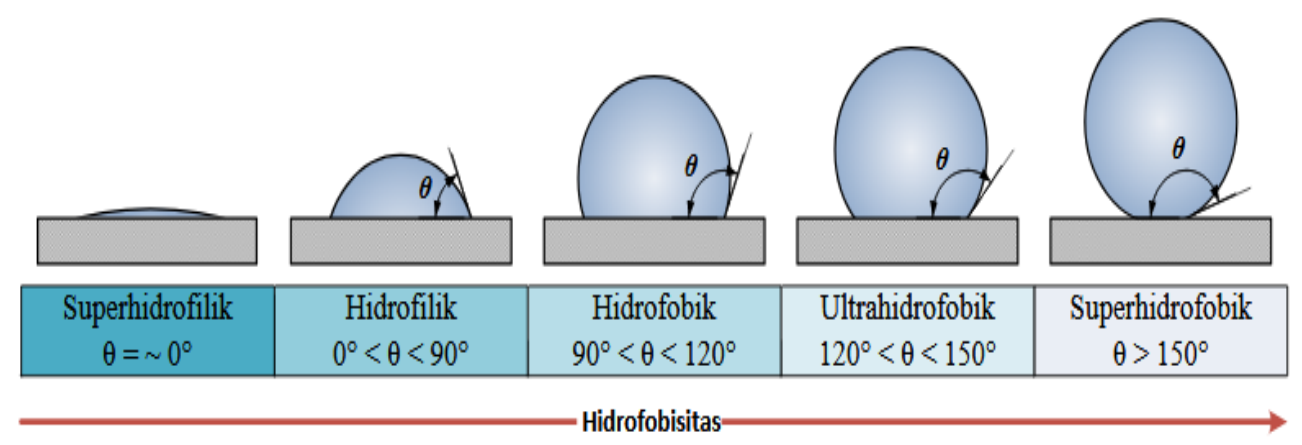

Gambar 1. Profil tetes air dan sudut kontak pada permukaan homogeny dengan hidrofobisitas berbeda.

\section{2b. Teori Wenzel pada Permukaan yang Heterogen}

Persamaan Wenzel digunakan untuk membahas persamaan sudut kontak cairan dengan permukaan padat yang kasar. Pertama yang perlu di pertimbangkan adalah tetesan 
(droplet) air di permukaan kasar dan antarmuka 115omogeny. Persamaan wenzel memperkenalkan persamaan yang digunakan untuk menjelaskan hubungan sudut kontak droplet dengan permukaan padat yang kasar 115omogeny. Besarnya area kontak akan semakin berkurang seiring dengan bertambah kasarnya permukaan. Pertama yang perlu dipertimbangkan adalah tetesan (droplet) air dipermukaan kasar antar muka Homogeny. Dengan menggunakan keseimbangan gaya permukaan dan pertimbangan empiris, sudut kontak dari droplet air pada permukaan solid ditunjukan pada Gambar 2.
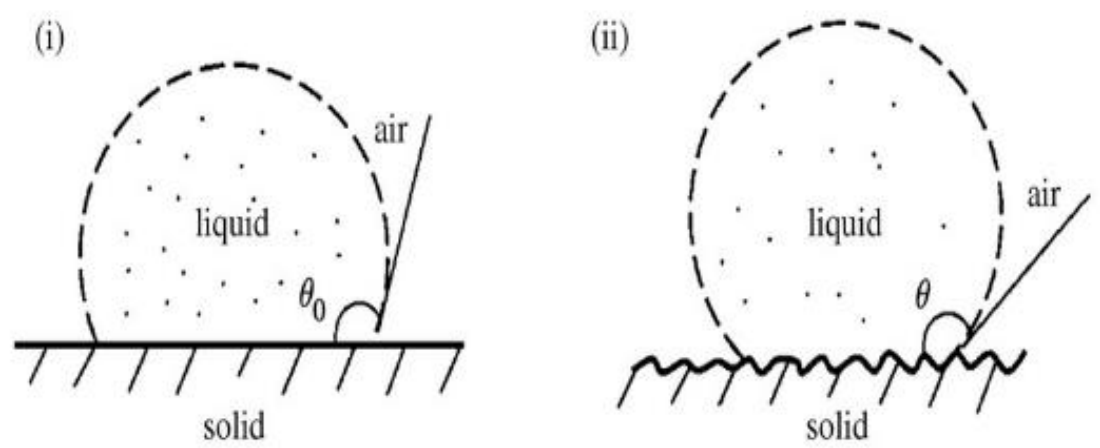

Gambar 2. (i)Perbandingan sudut kontak yang dihasilkan dari interaksi cairan permukaan untuk permukaan datar (ii) dan permukaan kasar

Gambar diatas memperlihatkan bahwa semakin kasar permukaan maka area kontak akan semakin berkurang dan besar sudut kontak akan bertambah. Penerapan kesetaraan tekanan permukaan dan beberapa data impiris menyebabkan besarnya sudut kontak pada permukaan yang kasar $\emptyset$, berkaitan dengan besarnya sudut kontak untuk permukaan datar $(\varnothing)$. Dengan faktor non-demensi kekasaran permukaan, $\mathrm{R} 1>1$, dan rasio luas permukaan untuk permukaan datar $\left(\mathrm{A}_{\mathrm{SL}} / \mathrm{A}_{\mathrm{F}}\right)$ (Wenzel, 1936).
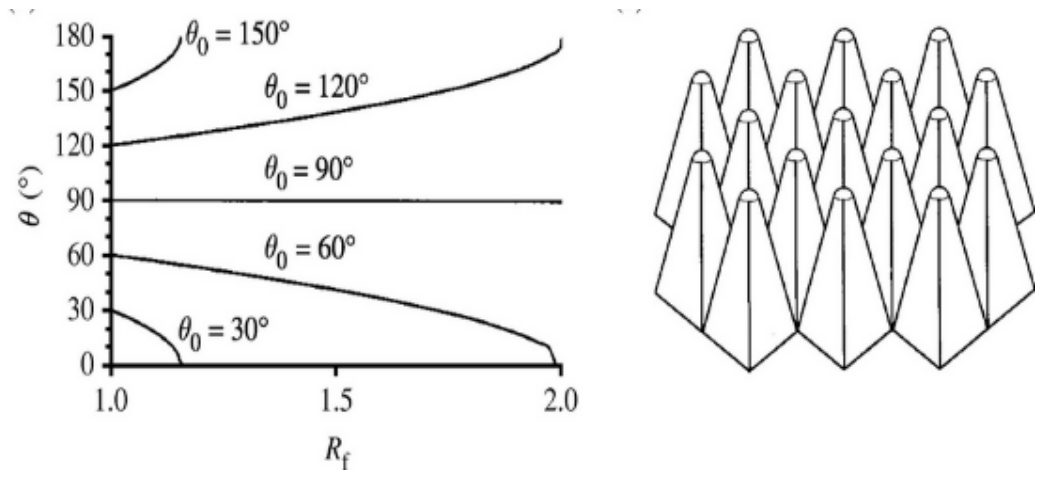

Gambar 3. (a) Hubungan antara faktor kekasaran permukaan $\left(\mathrm{R}_{\mathrm{f}}\right)$ terhadap sudut kontak (b) skematik berbasis hemispherical dengan puncak piramida asperities 
Ketergantungan dari sudut kontak pada faktor kekasaran pada Gambar 3(a) pada nilai yang berbeda dari $\emptyset_{0}$. Model wenzel memprediksi bahwa permukaan hidrofobik $\left(\emptyset^{0}>90^{\circ}\right)$ menjadi lebih hidrofobik dengan peningkatan $R_{f}$, sementara permukaan hidrofilik $\left(\varnothing^{0}<90^{\circ}\right)$ menjadi lebih hidrofilik dengan meningkatkan $R_{\mathrm{f}}$ (Nosonvsky dan Bhushan, 2005; Jung dan Bhushan, (2006). wenzel menemukan fakta bahwa permukaan kasar tidak semata membuat area kontak membesar, namun hal ini tergantung pada sifat asli permukaan. Pada permukaan hydrhophobic $\left(\emptyset_{0}>90^{\circ}\right)$, pengasaran permukaan akan berefek kepada semakin menolak air (superhydrhophobic). Sedangkan pada permukaan hydrophilic $\left(\emptyset_{0}>90^{\circ}\right)$, pengasaran permukaan justru akan berefek kepada semakin kecilnya sudut kontak sehingga membuat permukaan semakin menarik air (hydrophilic) (Latthe, Sanjay Subhash. 2012).

\section{METODE PENELITIAN}

Pada penelitian ini yaitu memiliki jenis penelitian eksperimen. Eksperimen adalah penelitian dimana ada perlakuan (treatment) terhadap objek penelitian. Sebagaimana telah diutarakan, penelitian eksperimen dapat memberikan penjelasan tentang "alasan mengapa". Hubungan sebab akibat dapat diketahui karena penelitian dimungkinkan untuk melakukan perlakuan (treatment) terhadap objek penelitian. Penelitian ini adalah penelitian dasar atau penelitian murni. Penelitian dasar adalah setiap penelitian yang bertujuan untuk meningkatkan kemampuan ilmiah atau untuk menemukan bidang penelitian baru tanpa suatu tujuan praktis tertentu. Artinya kegunaan hasil penelitian tidak segera dipakai, namun untuk waktu jangka panjang.

\section{3a. Prosedur Penelitian}

a. Persiapan penelitian

Siapkan alat dan bahan. Pertama-tama masukan fluida yang akan digunakan kedalam flexpen atau alat pengukur tetesan droplet dengan menggunakan suntikan kecil, aktifkan digital mikroskop usb pada posisi horizontal dengan cara mengkoneksikan dengan leptop dan mengaktifkan software amcap untuk mengambil gambar lalu setting perbesaran pada mikroskop, atur fokus mikroskop sehingga didapat Gambar yang paling jelas. 


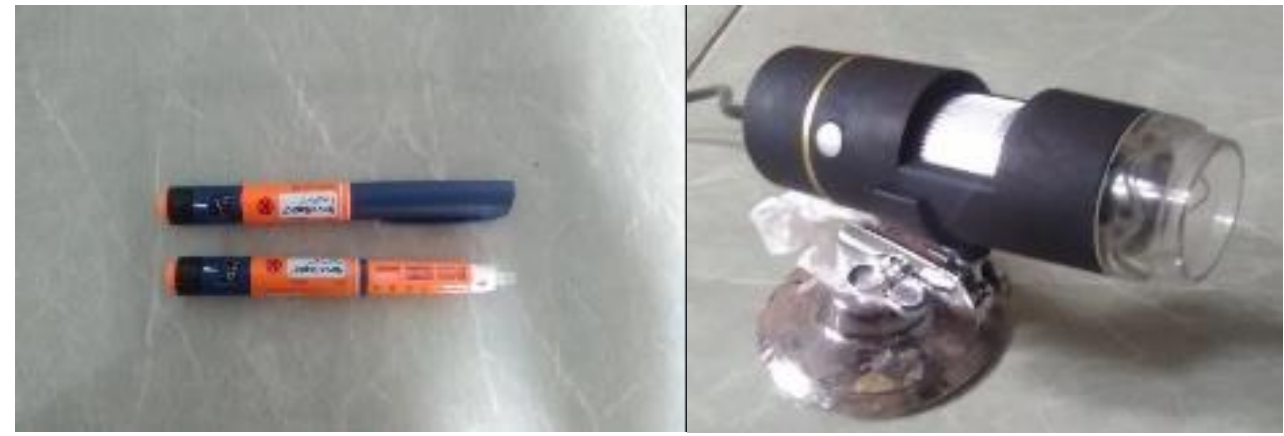

Gambar 4. Flexpen dan Mikroskop

\section{b. Pembuatan droplet}

Siapkan sampel daun yang segar pada ukuran diameter kurang lebih $15 \mathrm{~cm}$ dan cek sifat superhidrofobik, hidrofobik dan hidrofilik dengan cara meneteskan droplet air pada permukaannya, siapkan 3 cairan yang akan digunakan dalam penelitian ini. Untuk pengukuran jarak penetesan droplet pada permukaan daun yaitu $0,800 \mathrm{~mm}$. Selanjutnya rekatkan daun ke bagian tempat alasnya dengan menggunakan double tip untuk memastikan bahwa permukaan daun sedatar mungkin.

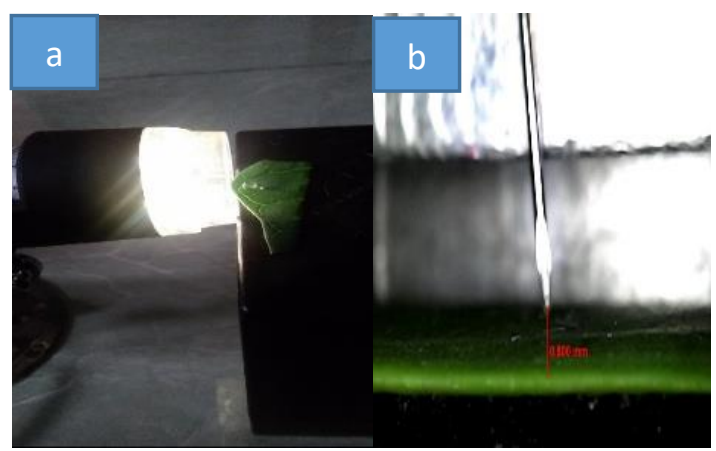

Gambar 5. (a) Pembuatan permukaan daun dan (b) Jarak Penetesan pada permukaan daun

c. Pengukuran dan pengambilan data

Teteskan droplet menggunakan flexpen per $1 \mathrm{ml}$ sampai $5 \mathrm{ml}$ sambil diamati dan difoto dengan digital mikroskop usb pada posisi horizontal untuk mengamati sudut kontak droplet per $1 \mathrm{~mm}$ seterusnya sampai $5 \mathrm{~mm}$. adapun pengujian yang dilakukan meliputi :

1. Melakukan penetesan pada daun menggunakan flexpen yang sudah di sediakan lalu lakukan pengukuran sudut dalam $1 \mathrm{ml}$ sampai $5 \mathrm{ml}$.

2. Mikroskop pada posisi horizontal untuk mengamati dan mengambil gambar perubahan sudut kontak droplet setiap $1 \mathrm{~mm}$ sampai $5 \mathrm{~mm}$ dengan menggunakan software amcap. 


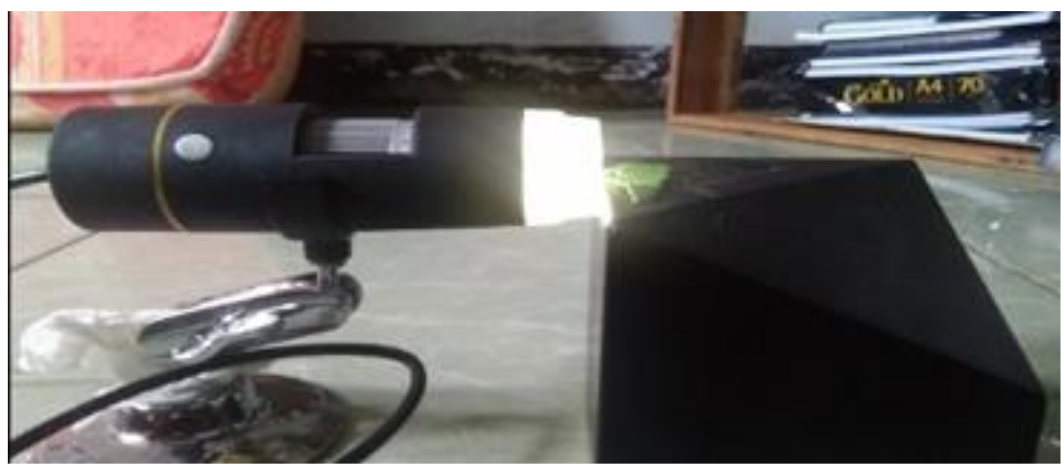

Gambar 6. Mikroskop pada posisi horizontal

Setelah didapat gambar yang diinginkan pada mikroskop posisi horizontal, selanjutnya dilakukan pengukuran sudut kontak pada droplet menggunakan software measurement dan amati pengaruh perubahannya.

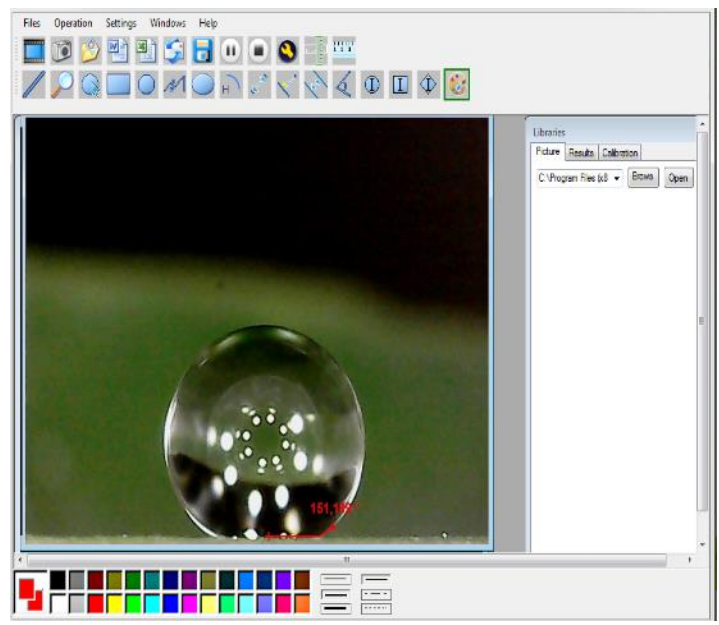

Gambar 7. Capture Suftware Measurement/Amcap

\section{3b. Teknik pengumpulan data}

Teknik pengumpulan data dalam penelitian ini dilakukan secara langsung. Data yang diperoleh secara langsung ini berupa volume fluida, bentuk permukaan sampel daun, foto sudut kontak. Untuk mengukur volume digunakan flexpen, melihat permukaan daun digunakan mikroskop dan SEM, untuk foto sudut kontak diambil dengan mikroskop portable. Pengukuran dilakukan satu persatu terhadap sampel.

\section{3c. Teknik pengolahan data}

Data yang didapat digambarkan dalam bentuk tabel dan grafik. Pengaruh fluida terhadap sudut kontak dapat diketahui dengan memplot data pada koordinat $\mathrm{X}$ dan $\mathrm{Y}$ menggunakan program Microsoft Excel. Secara umum dalam memplot data pada grafik 
$\mathrm{XY}$ digunakan teknik yaitu variabel bebas diplot ke sumbu $\mathrm{X}$ dan variabel terikat diplot ke sumbu Y.

\section{3d. Analisa data}

Data yang diperoleh akan dianalisa melalui tampilan grafik-grafik yang ada untuk mengetahui seberapa besar pengaruh fluida terhadap sudut kontak droplet pada permukaan daun kemudian dibuat pembahasan dan kesimpulan.

\section{3e. Diagram Alir}

Pada bagian ini dijelaskan langkah-langkah yang akan diambil dalam pelaksanaan penelitian. Adapun diagramnya ditunjukkan dalam Gambar 8, langkah pelaksanaan penelitian.

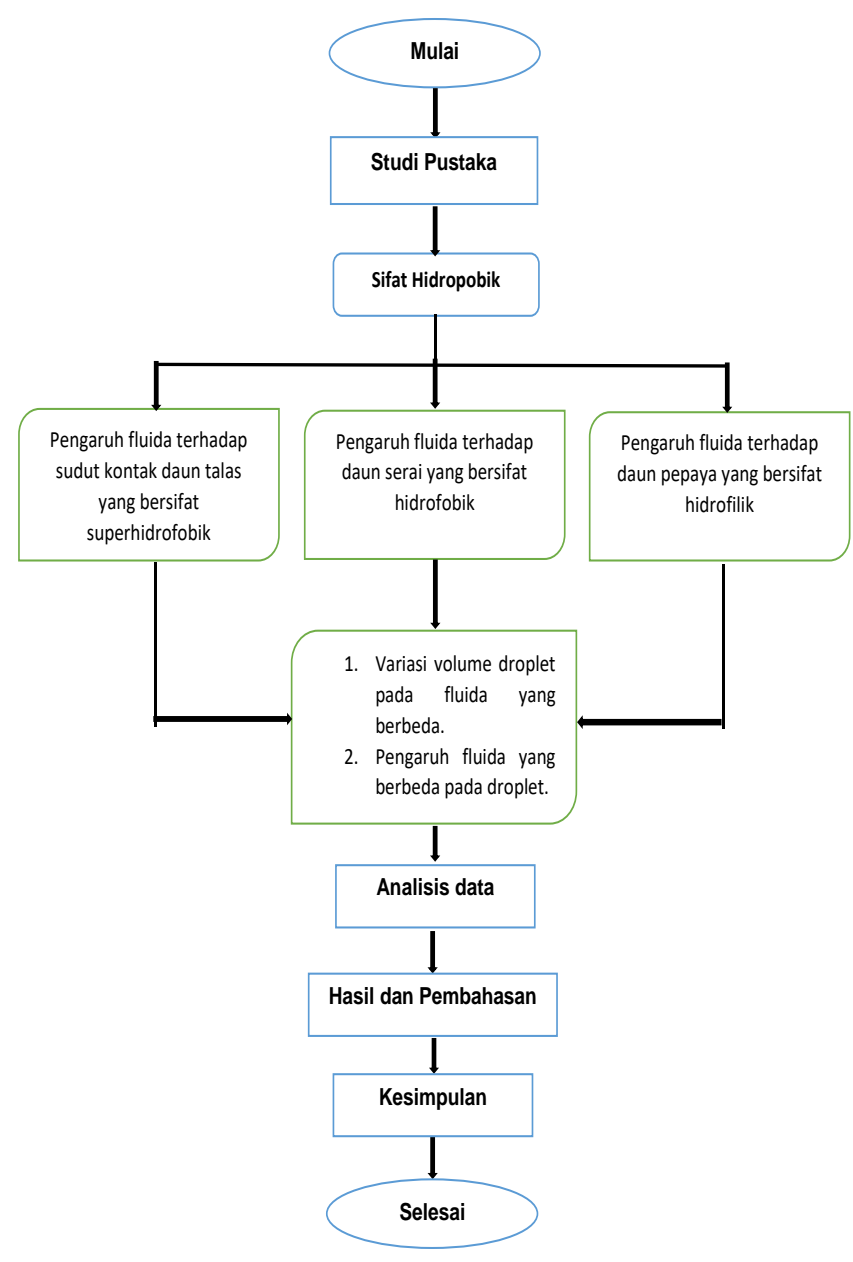

Gambar 8. Gambar diagram aliran penelitian 


\section{HASIL DAN PEMBAHASAN}

Pengambilan gambar droplet dilakukan menggunakan mikroskop digital dengan spesifikasi perbesaran sampai 1000x dan software amcap pada posisi horizontal untuk menangkap hasil gambar sedangkan pengukuran sudut kontak (contact angel) dilakukan secara langsung menggunakan software measurement pada hasil sudut kontak yang didapat pada penelitian. Software ini adalah software yang paling banyak digunakan untuk mengukur sudut kontak droplet pada penelitian sebelumnya karena dapat mengukur sudut kontak droplet dengan praktis dan presisi.

Untuk jarak penetesan droplet kepermukaan sebesar 0,800mm. Kekakuan homogenitas yang kurang dan kekasaran yang lebih besar menyebabkan pengaruh pada sudut kontak, yang pada selanjutnya akan menghasilkan ketergantungan pada ukuran volume tetesan sudut kontak. Untuk alasan ini, tetesan yang lebih besar dari $1 \mathrm{ml}$ tidak umum digunakan untuk mengukur sudut kontak (contact angel) dari droplet. percobaan ini menunjukkan teori ini benar, bahwa akan menyebabkan ketergantungan pada tetesan sudut kontak untuk permukaan yang lebih kasar dan kurang homogen.

\section{4a. Hasil Pengujian Droplet Alas Daun Talas (Superhidrofobik)}

Pengujian ini dilakukan di Laboratorium Teknik Mesin Universitas Lambung Mangkurat. Dari hasil pengujian droplet daun talas dengan menggunakan variasi fluida dengan ukuran volume droplet $1 \mathrm{ml}, 2 \mathrm{ml}, 3 \mathrm{ml}, 4 \mathrm{ml}$ dan $5 \mathrm{ml}$ dan jarak penetesan droplet pada alas $0,356 \mathrm{~mm}$, didapatkan hasil pengujian sebagai berikut:

Dari hasil pengujian droplet dengan daun talas dan fluida yang berbeda didapatkan hasil sudut kontak tertinggi $159,325^{\circ}$. Dari hasil pengujian sudut kontak menunjukan bahwa daun talas mempunyai sifat Superhidrofobik.

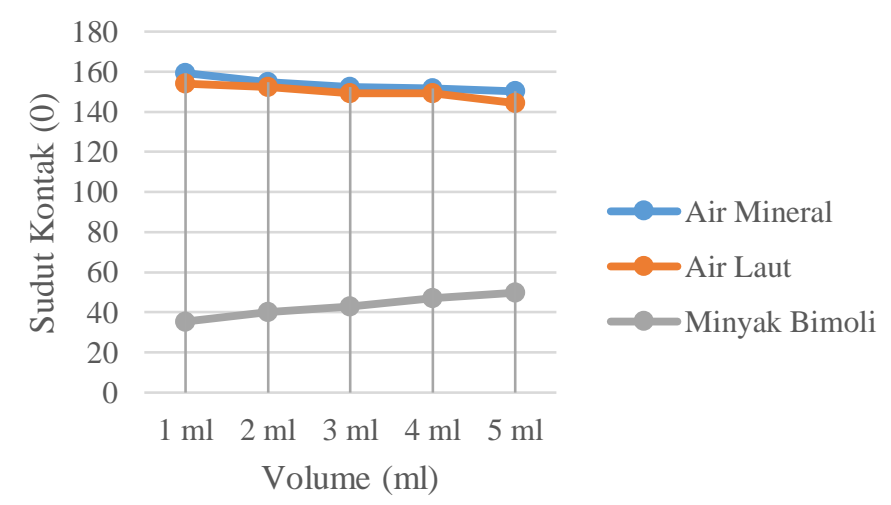

Gambar 9. Grafik Sudut Kontak Droplet Alas Daun Talas Menggunakan Fluida Air Mineral, Air Laut dan Minyak goreng 
Berdasarkan Gambar 9, hasil pengukuran droplet 1-5 $\mathrm{ml}$ menggunakan fluida air mineral dan laut menunjukan hasil sudut kontak menurun, pada minyak goreng bimoli hasil sudut kontaknya naik, hal ini karena disebabkan adanya lemak yang terdapat pada setiap daun hidrofobik, sehingga tidak berpengaruh terhadap sifat superhidrofobik, hidrofobik.

\section{4b. Hasil Pengujian Droplet Alas Daun Serai (Hidrofobik)}

Dari hasil pengujian droplet dengan daun serai dan fluida yang berbeda didapatkan hasil sudut kontak tertinggi $132,791^{\circ}$. Dari hasil pengujian sudut kontak menunjukan bahwa daun serai mempunyai sifat Hidrofobik.

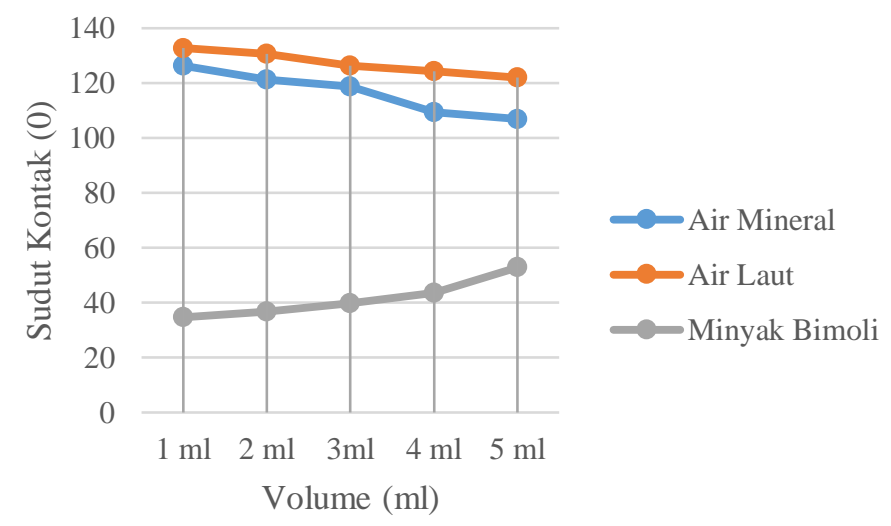

Gambar 10. Grafik Sudut Kontak Droplet Alas Daun Serai Menggunakan Fluida Air Mineral, Air Laut dan Minyak Goreng

Berdasarkan Gambar 10, hasil pengukuran droplet 1-5 ml menggunakan fluida air mineral dan laut menunjukan hasil sudut kontak menurun, pada minyak goreng bimoli hasil sudut kontaknya naik. hal ini karena disebabkan adanya lemak yang terdapat pada setiap daun hidrofobik, sehingga tidak berpengaruh terhadap sifat superhidrofobik, hidrofobik.

\section{4c. Hasil Pengujian Droplet Alas Daun Pepaya (Hidrofilik)}

Dari hasil pengujian droplet dengan daun pepaya dan fluida yang berbeda didapatkan hasil sudut kontak tertinggi $87,766^{\circ}$. Dari hasil pengujian sudut kontak menunjukan bahwa daun pepaya mempunyai sifat Hidrofilik. 


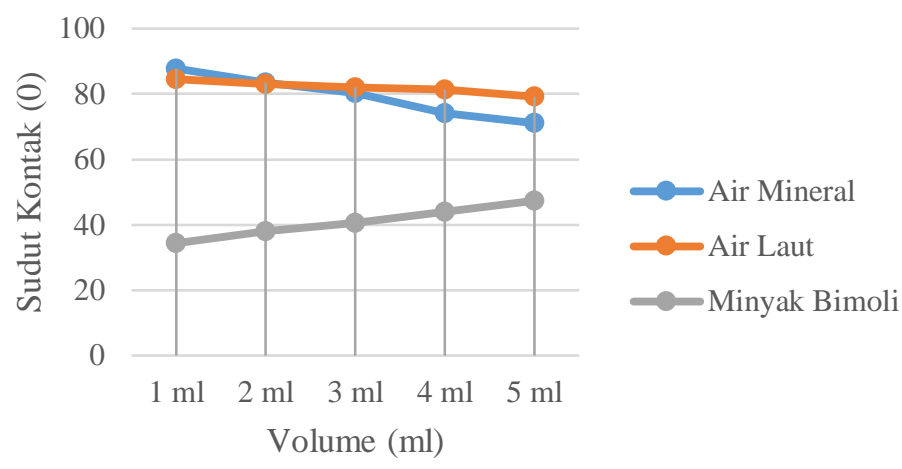

Gambar 11. Grafik Sudut Kontak Droplet Alas Daun Pepaya Menggunakan Fluida Air Mineral, Air Laut dan Minyak Goreng

Berdasarkan Gambar 11, hasil pengukuran droplet 1-5 ml menggunakan fluida air mineral dan laut menunjukan hasil sudut kontak menurun, pada minyak goreng bimoli hasil sudut kontaknya naik atau bersifat hidrofilik. Hal ini karena disebabkan adanya lemak yang terdapat pada setiap daun, sehingga tidak berpengaruh terhadap sifat superhidrofobik, hidrofobik, hidrofilik.

Berdasarkan hasil pengukuran sudut kontak droplet yang telah dilakukan menggunakan software measurement, percobaan pembuatan dan pengukuran sudut kontak dilakukan 1 kali sehingga didapatkan sudut kontak pada tabel - tabel diatas yang menggunakan berbagai macam alas yaitu daun talas (superhidrofobik), daun serai (hidrofobik) dan daun papaya (hidrofilik) dan pada fluida yang digunakan air mineral, air laut dan minyak goreng.

Masing - masing percobaan yang dilakukan dengan alas yang berbeda dan fluida yang berbeda. Pada alas daun talas diukur sudut kontanya pada ukuran volume tetesan droplet berbeda - beda. Dari hasil penelitian gambar 12, dapat dilihat bahwa pada percobaan dengan daun talas memiliki sudut kontak terbesar hingga $159,325^{\circ}$ pada volume $1 \mathrm{ml}$ pada percobaan menggunakan air mineral, pada percobaan menggunakan air laut sudut kontak terbesar hingga $154,011^{\circ}$ pada volume $1 \mathrm{ml}$ dan pada percobaan menggunakan minyak goreng bimoli sudut kontak terbesar hingga $49,807^{\circ}$ pada volume 5 $\mathrm{ml}$, berdasarkan setiap data diatas pada setiap permukaan dengan pengukuran sudut kontak yang terkait dalam setiap kasus. Dengan sudut kontak $159,325^{0}-154,011^{0}$ pada daun talas fluida air mineral dan air laut dengan tetesan volume droplet $1 \mathrm{ml}$ adalah superhidrofobik karena CA melebihi $150^{\circ}$. Pada alas daun serai di ukur sudut kontaknya pada ukuran volume tetesan droplet berbeda. Dari hasil pada tabel $4.7,4.8$ dan 4.9 diatas dapat dilihat sudut kontak tertinggi sebesar $132,791^{0}$ dengan volume $1 \mathrm{ml}$ menggunakan air mineral, pada percobaan dengan air laut didapat sudut kontak tertinggi sebesar 
$126,319^{0}$ dengan volume $1 \mathrm{ml}$, pada percobaan ini air laut lebih tinggi dari air mineral hasil sudut kontak dropletnya dapat dibuktikan pada data diatas bahwa alas daun serai dengan air laut bereaksi tingkat keasinannya. Dengan sudut kontak $132,791^{0}-126,319^{0}$ pada daun serai dengan tetesan droplet $1 \mathrm{ml}$ adalah hidrofobik karena CA kurang dari $150^{\circ}$. Selanjutnya pada alas daun papaya di ukur sudut kontaknya pada ukuran volume tetesan droplet yang berbeda. Dari hasil penelitian gambar 12, dapat dilihat hasil sudut kontak tertinggi sebesar $87,766^{\circ}$ dengan volume $1 \mathrm{ml}$ menggunakan air mineral, pada percobaan dengan air laut didapat sudut kontak tertinggi sebesar $84,523^{\circ}$ dengan volume $1 \mathrm{ml}$, pada percoban dengan minyak goreng didapat sudut kontak tertinggi sebesar $55,456^{\circ}$. Percobaan dengan alas daun papaya hasil uji cobanya tidak berpengaruh pada perbedaan fluida air mineral dan air laut hasil sudut kontak dengan tetesan droplet $1 \mathrm{ml}$ hampir sama. Dengan sudut kontak 87,766 $-84,523^{\circ}$ dengan volume droplet $1 \mathrm{ml}$ adalah hidrofilik karena CA kurang dari $90^{\circ}$.

Dari data hasil rata - rata pengukuran diatas diperoleh grafik yang dapat memberikan gambaran mengenai hasil penelitian. Data ini di ambil menurut hasil yang tertinggi pada penelitian yang dilakukan. Secara jelas dapat dilihat pada Gambar 12 sebagai berikut :

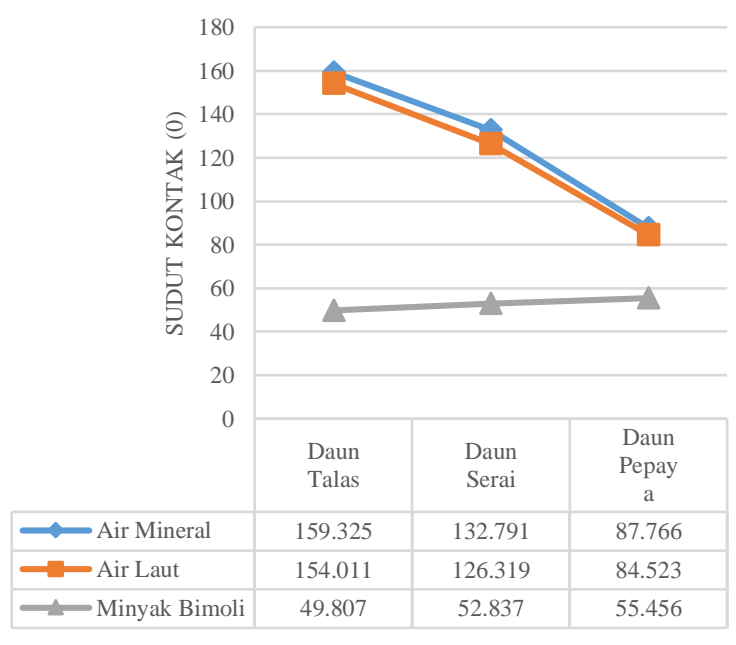

Gambar 12. Grafik hubungan antara variasi fluida dan variasi alas permukaan droplet

Pengaruh pada lapisan alas permukaan yang berbeda dapat diketahui bahwa sifat dari permukaan itu superhidrofobik, hidrofobik dan hidrofilik dengan menggunakan fluida yang berbeda, namun pada fluida minyak goreng setiap alas tidak berpengaruh terhadap sifat dari daunnya, karena daun talas memiliki kandungan kimia lemak yang terkandung 
didalamnya sehingga droplet yang ada pada daun talas menjadi hidrofilik. Pada daun serai memiliki kandungan kimia yang terdapat didalam tanaman serai mengandung 0,4\% minyak atsiri dengan komponen yang terdiri dari sitral, sitronelol (66-85\%), a-pinen, kamfen, sabinen, mirsen, $\beta$-felandren, $\mathrm{p}$-simen, limonen, cis-osimen, terpinol, sitronelal, borneol, terpinen-4-ol, $\alpha$-terpineol, geraniol, farnesol, metil heptenon, n-desialdehida, dipenten, metil heptenon, bornilasetat, geranilformat, terpinil asetat, sitronelil asetat, geranil asetat, $\beta$-elemen, $\beta$-kariofilen, $\beta$-bergamoten, trans-metilisoeugenol, $\beta$-kadinen, elemol, kariofilen oksida. (Anonim,1984; Anonim, 1985; dan Rusli dkk.,1979).

Minyak dan lemak adalah istilah umum untuk semua cairan organik yang tidak larut/bercampur dalam air (hidrofobik) tetapi larut dalam pelarut organik. Minyak adalah istilah untuk lipid yang bukan berasal dari hewan. Minyak atsiri merupakan jenis minyak yang dihasilkan dari tanaman. Minyak cenderung berbentuk cair pada suhu kamar, ini berbeda dengan minyak hewani atau yang lebih dikenal dengan lemak yang cenderung berbentuk padat. Lemak mengandung kolesterol, sedangkan pada minyak nabati mengandung fitosterol. Minyak lebih mudah menguap karena kaya akan ikatan ganda dan asam lemak tidak jenuh yang menyusunnya dibandingkan dengan lemak yang kaya akan ikatan asam lemak jenuh. (Fessenden dan Fessenden, 1997).

Pada daun pepaya memiliki kandungan nutrisinya relatif tinggi yaitu protein kasar 27,40\%; serat kasar 9,8\%; lemak kasar 10,0\%; abu 9,98\%; air 8,6\%, dan BETN 35,22\%. Daun pepaya juga mengandung papain yang merupakan salah satu enzim proteolitik, yaitu sejenis enzim yang membantu dalam proses pemecahan protein. Suhermiyati et al (1988). Alas permukaan daun yang diteteskan droplet diamati menggunakan mikroskop portable 1000x secara partikal untuk mengamati permukaan daun yang diteteskan droplet.

\section{KESIMPULAN}

Permukaan daun talas memiliki struktur hirarkis yang kasar heterogen sehingga hasil sudut kontak yang diperoleh lebih dari $150^{\circ}$ atau bisa dibilang superhidrofobik. Pada daun serai diperoleh sudut kontak kurang dari $150^{\circ}$ (hidrofobik) dan untuk daun papaya dapat dibuktikan bahwa daun papaya memiliki sifat hidrofilik karena sudut kurang dari $90^{\circ}$. Dengan adanya perbedaan permukaan alas dan fluida maka kita dapat mengetahui karakteristik dari sifat permukaan alas yang berbeda dan mengetahui sudut kontak yang dihasilkan disetiap alas. Pada fluida minyak dapat kita pastikan bahwa minyak tidak berpengaruh terhadap alas yang digunakan karena pada setiap daun memiliki kandungan lemak dan kalau minyak diteteskan dengan droplet minyak akan menyatu ke permukaan alas tersebut. 


\section{DAFTAR PUSTAKA}

1. Bhusan, B. dan Jung, Y.C., (2006) "Micro and nanoscale characterization of hydrophobic and hydrophilic leaf surface, nanotechnology 17 (2006) 2758-2772.

2. Bhusan, B. (2009). "Biomimetics: Lesson from nature-an overview, Phil. Trans. R. Soc. A" 367, 1445-1486.

3. Israelachvili, J. N. (1992). "Intermolectoral and Surface Forces, $2^{\text {nd }}$ edition". Academic Press, London.

4. Nosonovsky, M. and Bhusan, B. (2008h) "Superhydrophobicity for energy conversion and conservation applications" J. Adhesion Sci. Tech. 22 (2008h) 2105-2115.

5. Nosonovsky, M. and Bhusan, B. (2009a) "Multiscale effects and capillary interactions in functional biomimetic surfaces for energy conversion and green engineering". Phil. Trans. R. Soc. A 367 (2009a) 270-280. 